\title{
Effect of Plant Growth Regulators on Callus Formation In Stevia Rebaudiana
}

\author{
Adil Jawad*, Muhammad Naafe, Sikandar aman and Adil khan \\ Department of Horticulture, Faculty of Crop Production Sciences, The University of Agriculture, Peshawar
}

Submission: August 21, 2018; Published: September 27, 2018

*Corresponding author: Adil Jawad, Department of Horticulture, The University Of Agriculture, Peshawar Email: Muhammadnaafi11@gmail.com

\begin{abstract}
Stevia Rebaudiana Bertoni (natural sweetener) belongs to Asteraceae family and can be used as artificial sweeteners for diabetic patients. It has zero calories value and 300 times sweeter than sugar. Usually, it is cultivated by seeds or stem cutting, but seed viability rate is poor. The presented research was conducted to develop a standard protocol for the development and cultivation of stevia rebaudiana (Bert.). Experiment was conducted in the laboratory of nuclear institute of food and agriculture using complete randomize design (CRD) design including three replications and four treatments. In this study the effect of different Plant Growth Regulators (PGRs) on efficient regeneration of Stevia (S.) rebaudiana (Bert.) from the leaf explants has been investigated. Napthelic acetic acid and Benzyl amino purine (NAA+BAP) 2mg/Lshows a significant result as compared to a treatment of Basal, 2-4D 1mg/L, 2-4D 2mg/L. A suitable leaf was aseptically inoculated onto Murashige and Skoog (MS) medium for callus proliferation. Maximum average callus production (100\%), average fresh weight $(0.19 \mathrm{~g})$, Dry weight $(0.13 \mathrm{~g})$ was observed when a healthy leaf portions were treated with nepthelic acetic acid and Benzyl amino purine (NAA+BAP) $2 \mathrm{mg} / \mathrm{L}$. The leaf also produce root when it is aseptically cultured on (NAA+BAP) because nepthelic acetic acid are rooting hormones. However, leaf explants showed lower average callus production $(66.67 \%)$ average fresh weight $(0.18 \mathrm{~g})$ and average dry weight $(0.02 \mathrm{~g})$ when exposed to Basal medium. when the leaf was inoculated aseptically on 2, 4-dichlorophenoxyacetic acid(2-4D) 1mg/L. They produce the average callus production (100\%), average fresh weight $(0.93 \mathrm{~g})$, dry weight $(0.10 \mathrm{~g})$ and the leaf proliferate average callus $(100)$, average fresh weight $(0.77 \mathrm{~g})$, average dry weight $(0.17 \mathrm{~g})$.
\end{abstract}

Keywords: Stevia Rebaudiana; Callus Proliferation;NAA+BAP; 2-4; D

\section{Introduction}

Stevia Rebaudiana Bertoni commonly known as Stevia, Sweet leaf of Paraguay, Sweet herb, Honey leaf and it is indigenous to the family of Asteraceae. This is expected to be 100-300 times sweeter than cane sugar (Tanaka 0., 1982). The steviaplantis small perennial herb growth up to $65-80 \mathrm{~cm}$ tall, with arranged leaves, white flower in axillary heads. Stevia Rebaudianais native to the tropical and subtropical South America (Katamaya O, 1976). The leaf is sweeter due to the presence of an intensivesweetening agent known as stevioside. Stevioside is regenerated as a valuable natural sweetening agent because of its relatively good taste and chemical stability (Yamazaki and Flores, 1991), (Toyoda and Matsui, 1997). Stevia Rebaudiana has no calories and no calcium cyclamate therefore it is safe for diabetics,and has no effect on blood sugar levels; it does not have the nervous or renal side effects of some of the artificial sweeteners. Stevia being used as a sweetener is likely to become a major source of high effectiveness sweetener for the growing natural food market worldwide [1-24]. Seeds of stevia show very less vigor and do not allow the production of homogenous population which leads to variability in sweetening level and composition [25]. Successful exploitation of medicinal plants used as a key to address the huge number of problems associated with wideranging health, nutritional and social aspects of human being.
Special importance of stevia is as it is also non-caloric, nonfermentable and does not darken upon cooking [5].

The production of Steviolglycosides in the in vitro upraised cultures is poorly agreed, and the results obtained by different authors are contradictory. However, regeneration through micro propagation. Stevia was developed by many scientists in India [6]. Vegetative Propagation is also too slow having the chances of pathogen attack on the tissues [7]. Therefore, tissue culture techniques is an important techniques for propagation and preservation of plants of such an economic significance in which conventional methods show limitations $[8,9]$. Stevia is sweet herb of Paraguay, which comprises natural noncaloric sweetener and leaves of stevia contain a number of diterpenesteviol glycosides (SGs) which are estimated about 300 times sweeter than sucrose at their concentration of $4 \%(\mathrm{w} / \mathrm{v})$ [10]. There are nine types of steviol glycosides found in Stevia are; Stevioside, Rebaudioside A, Rebaudioside B, Rebaudioside C, Rebaudioside D, Rebaudioside E, Rebaudioside F, Steviolbioside A and Dulcoside A. It was described that these glycosides are non- toxic, non- mutagenic and low calorie complexes and unlike old sugar substitutes such as xylitol or sorbitol [11]. Because of non-caloric and sweetening properties stevioside has garnered care with the increase in demand for low-carbohydrate, and low- 
sugar food alternatives [12]. It has a strong antimicrobial action. In accumulation to the sweetening and antimicrobial properties, stevia plant has therapeutic values such as antihyperglycemic, antihypersensitive agent [13]. Currently, stevia is used both directly and after processing as a sweetener for tea, chocolate, jam, cookies, ice cream, juice and other soft drinks and yoghurt etc [14]. One of the most important ways of using in vitro techniques in breeding of stevia is its micro propagation. It is the fastest and most efficient method of obtaining a high number of plants in industrial scale, the plants homogenous in terms of composition and contents of steviol glycosides and free of diseases [15]. The usefulness of the method is further enhanced by the fact that stevia seeds are characterized with very low germination strength [16].

Due to the above-mentioned difficulties, plant tissue culture or micro propagation can be used for rapid propagation and conservation of such valuable and endangered plant species $[17,18]$. Stevia can regenerate by seeds, the plant growth regulators (PGRs) type and but they are very small in size and infertile. Also, the concentration on callus induction, explants were cultured seeds show a very low germination percentage, so large on MS medium supplement with benzyl adenine (BA) at scale mechanized production of stevia through seeds is $0.5 \mathrm{ppm}$ and either 2,4 dichlorophenoxy acetic acid (2,4-D) not fruitful [19]. Stevia rebaudiana (Bertoni), contains in its leaves all of the eight ent-kaurene glycosides that produce the sweet taste sensation with stevioside being the major constituent [20].

\section{Objectives}

a) To know about the effect of different concentration of 2,4 D on callus production of Stevia Rebaudiana.

b) To study the imbalance effect of BAP and NAA on callus proliferation on M.S media.

c) To investigate the control effect of callus (Stevia Rebaudiana) on M.S media.

d) To make a standard protocol for the propagation of Stevia Rebaudiana.

\section{Materials and Methods}

At biotechnology lab of Nuclear Institute for Food and Agriculture Tarnab Farm, Peshawar this research activities is carried out. Different concentration of 2,4dichlorophenoxyaciticacid and (NAA+BAP) was used to find the effects of callus induction.

\section{Experiment (Table 1).}

Table 1.

\begin{tabular}{|c|c|}
\hline Treatment & Media concentration \\
\hline T0 & MS basal \\
\hline T1 & $2-4 \mathrm{D} 1 \mathrm{mg} / \mathrm{L}$ \\
\hline $\mathrm{T} 2$ & $2-4 \mathrm{D} 2 \mathrm{mg} / \mathrm{L}$ \\
\hline $\mathrm{T} 3$ & $(\mathrm{BAP}+\mathrm{NAA}) 2 \mathrm{mg} / \mathrm{L}$ \\
\hline
\end{tabular}

Glass Jar (baby jars): $100 \mathrm{ml}$ Glass jar fill with the MS medium by the volume 30 to $40 \mathrm{ml}$ and place for s gelling before the culture a plant material in glass jar.

Forceps: Forceps used for the holding of callus.

Petri Dish: Petri dish is used during culturing of plantlets.

Surgical Blades and its Holder: Blade used for cutting the plant material and holder used to hold the blade.

Autoclave: Autoclave used for sterilization of glassware, forceps, and other laboratory equipment.

Laminar Flow Bench: It is used to provide a clean free germs environment for culturning.

PH Meter: A PH meter is used to balance the acidity or alkalinity of MS media

Oven: An oven is useful for sterilization of glass-wares such as petri-dishes, pipets and others. Used for the heating of MS media to dissolve agar.

Electromagnetic stirrer: Magnetic stirrer can be used for mingling the MS medium stock solution

Volumetric cylinder: Volumetric cylinder can used to measure the MS media

Sterilization room: It is used for washing the laboratory equipments

Culture room: Culturing of explant were done in culturing room.

Growth chamber: Growth chamber is a place where the culture plantlets should be kept in aseptic condition there should be proper lightening humidity temperature according to the behaviour of the plant.

Glassware Preparation: All the glasswere washed carefully with market available detergents. All of them washed 3 times with distilled water and then sterilized for 60 minutes at $200{ }^{\circ} \mathrm{C}$ in electric oven. All the instruments sterilized by autoclaving at $1210 \mathrm{C}$ at 15 -psi (0.1mpa) for 20 minutes before using.

Preparation of stock solutions: Murashige and skoog MS (1962) medium was used as basic medium for invitro propagation. Stocks solutions of micro and macro nutrients iron and vitamins were prepared using following procedure. All the components were properly measured and dissolved individually in distilled water and final volume adjusted to 1 liter. Each component was mixed by using electric stirrer after weighted on electric balance. The prepared solutions were stored at $4{ }^{\circ} \mathrm{C}$ till using in the experiment (Table 2).

Stock Solution for Plant Growth Regulator: Stock solution for each of the different plant growth regulators were prepared by dissolving $0.1 \mathrm{~g}$ or $100 \mathrm{mg}$ of each constitute in distilled water up to a final volume of $100 \mathrm{ml}$ diluted acid for cytokinins and diluted base or alcohol for auxins were used as solvent. 


\section{International Journal of Environmental Sciences \& Natural Resources}

Table 2.

\begin{tabular}{|c|c|c|c|}
\hline & Macro nutrients & grams $/ 1000 \mathrm{ml}$ or liter & Volume of stock liter/ of medium (ml/liter) \\
\hline 1 & $\mathrm{MgSO}_{4} \times 7 \mathrm{H}_{2} \mathrm{O}$ & 7.4 & \multirow{5}{*}{$50 \mathrm{ml}$} \\
\hline 2 & $\mathrm{CaCl}_{2} \times 2 \mathrm{H}_{2} \mathrm{O}$ & 8.8 & \\
\hline 3 & $\mathrm{KNO}_{3}$ & 38.0 & \\
\hline 4 & $\mathrm{NH}_{4} \mathrm{NO}_{3}$ & 33.0 & \\
\hline 5 & $\mathrm{KH}_{2} \mathrm{PO}_{4}$ & 3.4 & \\
\hline B & Micro nutrients & grams $/ 1000 \mathrm{ml}$ or liter & \multirow{8}{*}{$5 \mathrm{ml}$} \\
\hline 1 & $\mathrm{MnSO}_{4} \times 4 \mathrm{H}_{2} \mathrm{O}$ & 4.4 & \\
\hline 2 & $\mathrm{ZnSO}_{4} \times 7 \mathrm{H}_{2} \mathrm{O}$ & 1.72 & \\
\hline 3 & $\mathrm{CuSO}_{4} \times 5 \mathrm{H}_{2} \mathrm{O}$ & 0.01 & \\
\hline 4 & $\mathrm{CoCl}_{2} \times 6 \mathrm{H}_{2} \mathrm{O}$ & 0.005 & \\
\hline 5 & $\mathrm{KI}$ & 1.67 & \\
\hline 6 & $\mathrm{H}_{3} \mathrm{BO}_{3}$ & 1.24 & \\
\hline 7 & $\mathrm{Na}_{2} \mathrm{MoO}_{4} \times 2 \mathrm{H}_{2} \mathrm{O}$ & 0.05 & \\
\hline C & Vitamins & grams $/ 1000 \mathrm{ml}$ or liter & \multirow{6}{*}{$5 \mathrm{ml}$} \\
\hline 1 & Myo-Inositol & 20.0 & \\
\hline 2 & Nicotinic acid & 0.1 & \\
\hline 3 & Pyridoxine HCL & 0.1 & \\
\hline 4 & Thiamine HCL & 0.1 & \\
\hline 5 & Glycine & 0.5 & \\
\hline D & Iron Solution & grams $/ 500 \mathrm{ml}$ & \multirow{3}{*}{$5 \mathrm{ml}$} \\
\hline 1 & $\mathrm{FeSO}_{4} \times 7 \mathrm{H}_{2} \mathrm{O}$ & 2.78 & \\
\hline 2 & $\mathrm{Na}_{2}$ EDTA & 3.73 & \\
\hline
\end{tabular}

Culture media: Murashige and skoog (MS) Medium (1962) was prepared from these stock solutions the media were then added with $3 \%$ of sucrose and various plant regulators according to experimental requirement the ph was adjusted at 5.6 to 5.8 before autoclaving at $121 \mathrm{C}$ at $15 \mathrm{psi}(0.1 \mathrm{mpa})$ for 20 minutes to solidify agar at of 7.0 concentration was used.

\section{Selection of explant for callus and leaf sterilization}

Take the fresh and top leaves which were good for callus induction and strong meristematic tissues. Fast growing young Leaves were selected from NIFA field. Leaf explant was first washed with running tap water for 15 minutes to eradicate dust particles. Surface sterilization was done by putting the explant

Result and Discussion

Table 3.

\begin{tabular}{|c|c|c|c|c|c|}
\hline Basal treatment & Callus morphology & Callus colour & Callus percentage & Callus fresh weight(gm) & callus dry weight \\
\hline Rep 1 & Granulla-spongy & whitish -yellow & 66.67 & 0.21 & 0.03 \\
\hline Rep 2 & Granulla-spongy & whitish -yellow & 66.67 & 0.18 & 0.01 \\
\hline Rep 3 & Granulla-spongy & whitish -yellow & 66.67 & 0.16 & 0.01 \\
\hline Average & & & 66.67 & 0.18 & 0.02 \\
\hline
\end{tabular}

The experiment was conducted under CRD design using three replications and four treatments. The experiment was carried out in the laboratory of nuclear institute of food and agriculture Turnab Peshawar.MS medium without plant growth regulators (PGRs) was not found to best for callus production. in $70 \%(\mathrm{v} / \mathrm{v})$ ethanol for 60 seconds and then in $0.1 \%(\mathrm{w} / \mathrm{v})$ mercuric chloride $\left(\mathrm{HgCl}_{2}\right) 1$ minute. Then explant washed with sterilized distilled water Three times.

Aseptic Transfer of Explant: Aseptic transfer of explant was cultured in laminar flow bench. Liminar flow bench was cleaned before using with $70 \%$ ethanol. Then prepare media all related equipments were exposed to UV light for 20 minutes. The explant were then cultured in $100 \mathrm{ml}$ jars containing 30-40 ml.

Growth Conditions: Leaf explants were successfully cultured aseptically on MS as basic medium incorporated with $3 \%$ sucrose and $7.5 \%$ agar. The cultured jars were placed in a 16-light/8-dark hrs photoperiod at $25^{\circ} \mathrm{C}$. 


\section{International Journal of Environmental Sciences \& Natural Resources}

(100\%). The minimum and poorest response (66.67\%) was documented at MS basal medium. This has no plant growth regulators (PGRs). Primarily at low concentrations a smaller amount of callus formation was detected but as a concentration of 2, 4-D was increased the callus initiation response also increased. When (BAP+NAA) was supplemented to the basal MS Table 4.

\begin{tabular}{|c|c|c|c|c|c|}
\hline T-1 $1 \mathrm{mg} / \mathrm{L}$ & Callus morphology & Callus colour & Callus percentage & $\begin{array}{l}\text { Callus fresh } \\
\text { weight(gm) }\end{array}$ & $\begin{array}{c}\text { callus dry } \\
\text { weight(gm) }\end{array}$ \\
\hline Rep 1 & Granulla-Compact & Yelllow- green & 100 & 1.11 & 0.07 \\
\hline Rep 2 & Granulla-Compact & Brown-green & 100 & 1.03 & 0.13 \\
\hline Rep 3 & Granulla-Compact & Greenish-brown & 100 & 0.16 & 0.01 \\
\hline Average & & & 100 & 0.93 & 0.10 \\
\hline
\end{tabular}

Table 5.

\begin{tabular}{|c|c|c|c|c|c|c|}
\hline T-2 & $2,4 \mathrm{~d} 2 \mathrm{mg} / \mathrm{L}$ & Callus morphology & Callus colour & Callus percentage & Callus fresh weight(gm) & callus dry weight \\
\hline & Rep 1 & Granulla-Compact & Brown & 100 & 1.47 & 0.07 \\
\hline & Rep 2 & Granulla-Compact & Brown & 100 & 1.32 & 0,15 \\
\hline & Rep 3 & Granulla-Compact & Greenish-brown & 100 & 0.77 & 0.17 \\
\hline & Average & & & 100 & 1.19 & 0.13 \\
\hline
\end{tabular}

Table 6.

\begin{tabular}{|c|c|c|c|c|c|c|}
\hline T-3 & NAA+BAP 1mg & Callus morphology & Callus colour & Callus percentage & Callus fresh weight(gm) & callus dry weight \\
\hline & Rep 1 & Granulla-Compact & Green & 100 & 1.66 & 0.18 \\
\hline & Rep 2 & Granulla-Compact & Green & 100 & 1.17 & 0.25 \\
\hline & Rep 3 & Granulla-Compact & Green & 100 & 2.11 & 0.19 \\
\hline & Average & & & 100 & 1.65 & 0.21 \\
\hline
\end{tabular}
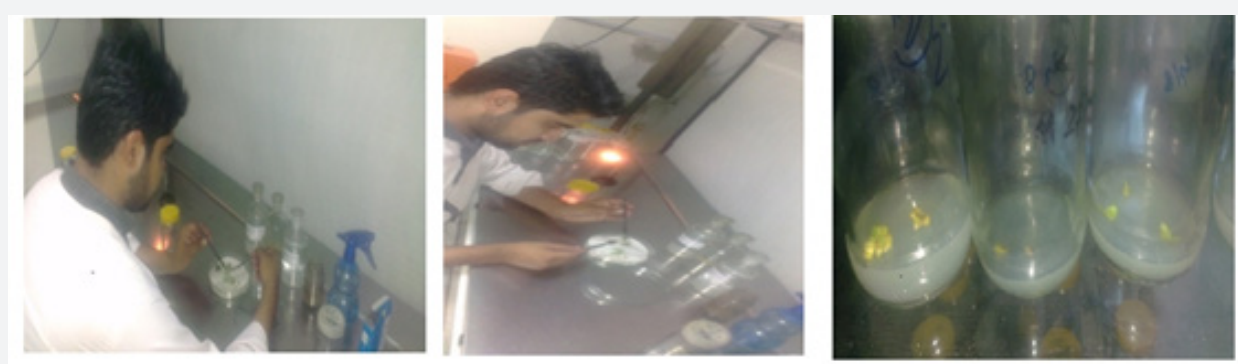

Figure 1: Growth Chamber.
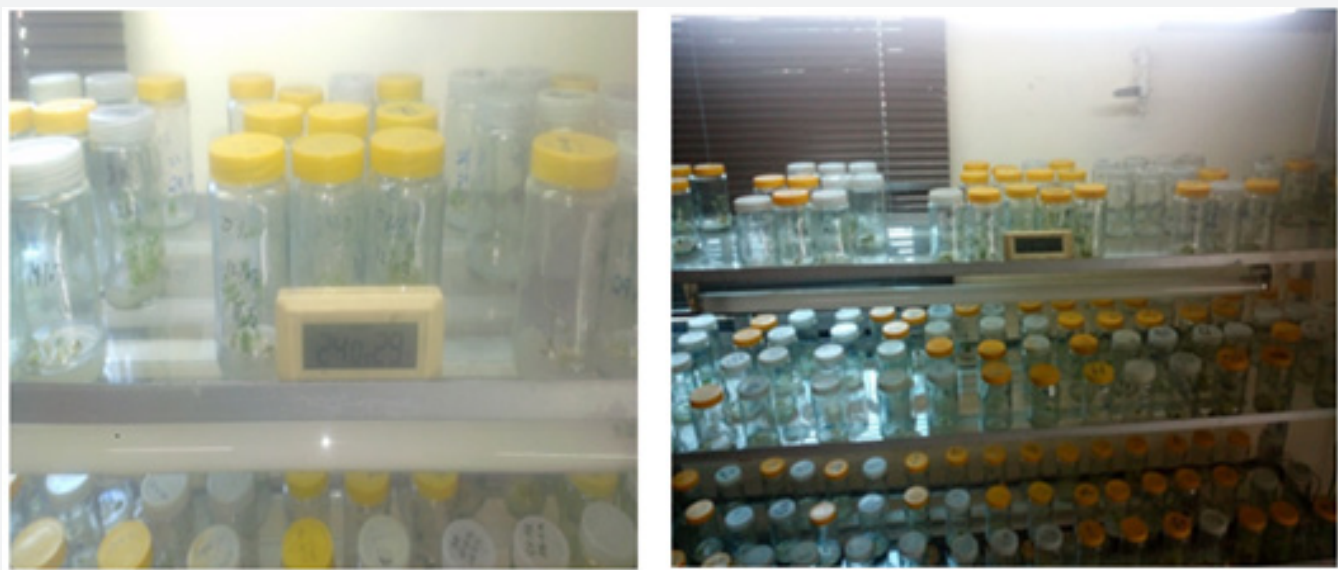

Figure 2: Callus Pictures. 

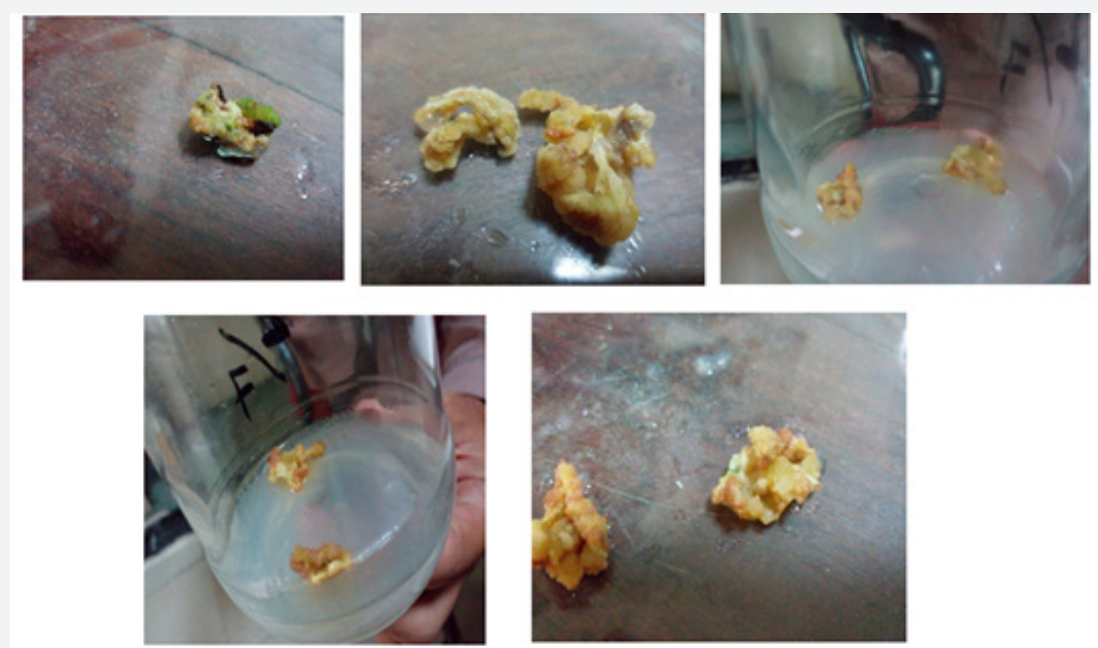

Figure 3

\section{Conclusion}

It was concluded from experiment that nepthelic acetic acid and benzyl amino purine (BAP+NAA) play a vital role in the maximum formation of callusing and also play a key role in root formation. It was found that nepthelic acetic acid and benzyl amino purine (NAA+BAP) resulted in a maximum callus formation from leaf explants (100\%). The callus morphology are granulla-compact, callus color green, average of callus fresh weight $(1.65 \mathrm{~g})$ and average of callus dry weight $(0.21 \mathrm{~g})$ The minimum and poorest response $(66.67 \%)$ was documented at MS basal medium.

\section{References}

1. Tanka O (1982) steviol glycosides: new natural sweetener. Trand and chem 1(11): 246-248.

2. Katayma O, Sumida T, hayashi H, Mitsuhashi H (1976) The practical application of stevia and R and D data (English translation). ISU company japan p. 747.

3. Robinson BL (1930) Contributions from the Grey Herbarium of Harvard University. The Grey Herbarium of Harvard University, Cambridge.

4. Sakaguchi M, T Kan (1982) Japanese researches on Stevia RebaudianaBertoni and stevioside. Ci Cult 34: 235-248.

5. Crammer B, Ikan R (1986) Sweet glycosides from the Stevia plant. Chem Britain 22: 915-916.

6. P Gupta, S Sharma, S Saxena (2010) Micropropagation of Stevia Rebaudiana (natural sweetener using Kinetin for Steviol glycoside Production, Research journal of Biotechnology 5(1): 63-67.

7. Debnath M (2008) Clonal propagation and antimicrobial activity of an endemic medicinal plant Stevia rebaudiana. Journal of Medicinal Plant Research 2: 45-51.

8. Yadav K, Aggarwal A, Singh N (2013a) Evaluation of genetic fidelity among micropropagated plants of Gloriosasuperba L using DNA based markers a potential medicinal plant. Fitoterapia 83: 265-270.

9. Yadav K, Aggarwal A, Singh N (2013b) Arbuscularmycorrhizal fungi (AMF) induced acclimatization, growth enhancement and colchicine content of micro propagated Gloriosasuperba L plantlets. Industrial Crops and Products 45: 88- 93.
10. AD Kinghorn, DD Soejarto (1986) Sweetening agents of plant origin. Crit Rev Plant Sci 4, pp. 79-120.

11. AG Lyakhovkin, TD Long, DA Titov, MP Anh (1993) In Cultivation and utilization of (Stevia RebaudianaBertoni)", Agricultural Publishing House, Hanoi pp. 1-44.

12. Kalpana M, Anbazhagan M, Natarajan V (2009) Utilization of liquid medium for rapid multiplication of Stevia Rebaudiana. J Ecobiotechnol 1(1): 016-020.

13. Chan P, DY Xu, JC Liu, YJ Chen, B Tomlinson (1998) The effect ofstevioside on blood pressure and plasma catechol amines in spontaneously hypertensive rats. Life Sci 63(19): 1679-1684.

14. Ibrahim IA, Nasr MI, Mohammed BR, El Zefzafi MM (2008) Nutrient factors affecting in vitro cultivation of SteviaRebaudiana. Sugar Tech 10(3): 248-253.

15. Sivaram L, Mukundan U (2003) In vitro culture studies on Stevia Rebaudiana. Vitro Cell DevBiol Plant 39(5): 520-523.

16. Carneiro JWP, Muniz AS, Guedes TA (1997) Greenhouse bedding plant production of Stevia Rebaudiana (Bert). Bertoni Can J Plant Sci 77(3): 473-474.

17. Nalawade SM, PS Abhay, L Chen Yue, K Chao Lin, T Hsin Sheng (2002) Studies on tissueculture of Chinese medicinal plant resources in Taiwan and their sustainable utilization. Bot Bull Acad Sin 44(2): 79-98.

18. Debnath M, CP Malik, PS Bisen (2006) Micropropagation A Tool for the Production of High-Quality Plant based Medicines. Curr Pharm Biotechnol 7(1): 33-49.

19. Savita SM, K Sheela, S Sunanda, AG Shankar, P Ramakrishna (2004) Stevia Rebaudiana A Functional Component for Food Industry. J Hum Ecol 15(4): 261-264.

20. Kinghorn AD, Soejarto NPD, Nanayakkara CM (1984) A phytochemical screening procedure for sweet ent-kaurene glycosides in the genus Stevia. J Nat Prod 47(3): 439-444.

21. Toyoda K, Matsui H (1997) Assessment of the carcinogenicity of stevioside in F344 rats. Food Chem Toxicol 35(6): 597-603.

22. Yamazaki T, HE Flores (1991) Examination of steviolglucosides production by hairy root and shoot cultures of Stevia Rebaudiana. J Natural Products 54 (4): 986-992.

23. Matsui M, Matsui K, Kawasaki Y (1996) Evaluation of the genotoxicity of stevioside and steviol using six in vitro and one in vitro mutagenecity assays, Mutagenesis 11(6): 573-579. 
24. Shen XL, Xu Z (1997) Studies on micro propagation of Stevia RebaudianaII. Effect of basic culture medium and carbon source on callus formation and morphogenesis. Sugar Crop of China 4:9.
25. Felippe GM, Lucas NMC (1971) Estudo da viabilidade dos fructos de SteviaRebaudiana Bert. Hoehnea, 1: 95-105.

Your next submission with Juniper Publishers will reach you the below assets

- Quality Editorial service

- Swift Peer Review

- Reprints availability

- E-prints Service

- Manuscript Podcast for convenient understanding

- Global attainment for your research

- Manuscript accessibility in different formats ( Pdf, E-pub, Full Text, Audio)

- Unceasing customer service

Track the below URL for one-step submission https://juniperpublishers.com/online-submission.php 